\title{
Creative approach to development of competence "writing" in foreign language classes
}

\author{
Irena V. Aleshchanova ${ }^{1,{ }^{*}, \text { Natalia A. Frolova }}{ }^{1}$, and Marina R. Zheltukhina ${ }^{2}$ \\ ${ }^{1}$ KTI (branch) of VSTU, Foreign Languages and Humanities Department, 403874 Kamyshin Lenin Street 6A, Russia \\ ${ }^{2}$ VSSPU, Theory of English Department, 400066 Volgograd, Lenin Av. 27, Russia
}

\begin{abstract}
This study examines the question of development of an important component of the foreign language communicative competence - the skill of writing as a structural element of the technical university students' professional competence. The methods and ways of the stated aim achievement are analyzed from the perspective of the competence and personality-oriented approaches. Professional communication is presented as a multicomponent phenomenon, requiring detailed study. Foreign and domestic research in the field of foreign language teaching formed the theoretical basis for studying the methodical and didactic aspects of writing activities. The authors define students' acquisition of writing skills in the process of education as the development of elementary communicative competence. Tasks for the writing skills development are described as a productive tool for organizing educational activities. The authors emphasize the special role of creative tasks and how they can contribute to achieving the set goals in teaching. Practical recommendations on the development of writing skills and this process monitoring are given.
\end{abstract}

\section{Introduction}

The recent trends towards globalization and internationalization have increased functional significance of foreign languages. In this connection, issues of teaching the communicative aspect of a foreign language have become especially important in the system of professional education. Teaching a foreign language is aimed at developing the foreign language communicative competence of a future specialist who is to use a foreign language in all its forms for professional communication in the scientific, technical, production and educational spheres.

The foreign language communicative competence is defined as acquired in the educational process individual ability to put into practice appropriate models of speech behavior in a foreign language in stereotype communicative situations. In other words, the concept of "competence" is described in this paper as a person's ability to practical activities, the contents of which are the skills of communicative activity.

\subsection{Methodology}

The task of the article is to study the process of development of such an important component of the future specialist's foreign language communicative competence as the skill of writing. The development of skills in organizing and maintaining written communication requires the implementation of a number of practical recommendations, both on the choice of effective methods for acquiring it, and on finding ways to overcome some of the arising difficulties.

The results of the analysis and generalization of observational data of the development and improvement of the communicative writing skills in the educational situations of the technical university students' foreign language acquisition were used as the material of the study.

\subsection{Results and discussion}

The contents of foreign language teaching at a technical university provides for retention and further improvement of the general educational level of language proficiency combined with deep profile language learning aimed at using the acquired knowledge in the sphere of future professional activity including written personal and business contacts.

The theoretical aspect of the skill of writing is based on the most important concepts of the terminological apparatus of the communicative process description. It includes the concepts of communicative strategy, communicative behavior, conventions of linguistic material selection and communicative interaction organization, influence of socio-psychological and linguistic factors, receptive behavior as an adequate understanding of the interlocutor's verbal actions [1-3].

The applied description of the skills of writing is focused on the search for new methods of educational work, corresponding to the goals of a competent specialist formation. The productive aspects of teaching

*Corresponding author: dfl@ kti.ru 
writing in a foreign language can be effectively explicated in the implementation of project-based methods, game technologies, interactive education [4-6]. Creative methods of students' writing activities as composition of stories and story continuation of the existing stories with previously defined semantic support are considered in this paper.

The practice of teaching a foreign language reveals that most students experience certain difficulties in doing productive written exercises [8-9]. When preparing a relatively uncontrolled written work, students can realize the likelihood of making numerous mistakes affecting the meaningful quality of the texts. Neither students nor their teachers as participants of the educational process can assess positively these results of educational activity [10]. Consequently, the attempts to obtain a mutually desired result from creative written exercises are influenced by the above demotivating factors, which can be the cause of a possible failure [11-13].

The selection of an effective method for creative writing skills development both in professionally oriented foreign language classes and in additional classes in the university linguistic center has become an important educational task.

To complete this task, the comic book was chosen as a productive learning tool. It is considered in this study as a semantic base in the development of the above competence. Its use in the educational practice is universal and can be adapted to any age and language level [14-22].

The connection between the research conducted and the main contents of language education and teaching methods for foreign languages is as follows:

- there is insufficient empirical evidence that certain learning objectives should be achieved only by certain methods or that certain methodical techniques can provide the same educational outcomes for all learners;

- effective learning can be described as an educational process that results in the achievement of the meaningful learning objective;

- entertaining forms of creative writing are designed to raise motivation and / or to remove certain difficulties in learning;

- A person-oriented and practice-oriented approaches to learning require assessment and due consideration to the specific character of each learning group, which greatly minimizes the possibilities of a universal training manual development. In consequence, the use of a basic manual in combination with additional materials, the substitution of a less useful educational material with more productive one can help in the rational organization of an effective process of foreign language learning.

All of the above proves the validity of the introduction of comic books as a semantic base in the educational process practice. It should be noted that the final written product could not be described as entirely personal students' written work, since the plot is pre-set from the outside. However, the obvious plot intrigue in itself softens the communication barriers, which allows students to "create" and develop their writing skills in quite a free form [23-24].
This study involved the formulation and solution of the following issues:

- What outcomes will be obtained when the comic book is introduced into learning practice and students are taught to write using it?

- Will the use of the comic book patterns improve the quality of writing and the final written product contents?

- What positive changes in the educational process can be detected during the observation process?

- What changes will the students notice?

A number of indicators were identified in the process of conducted observations. They formed the base for drawing conclusions about the effectiveness of comic book patterns in creative writing:

- students prepare a written plan using the comic book patterns. It serves as a support in preparation of a creative written task. The new method does not cause any difficulties and favorably affects the process of working with the comics patterns ( $\rightarrow$ observed);

- the larger part of the students' personal contribution to the written product is correct in terms of language and is significant in contents ( $\rightarrow$ observed);

- students do a written task in the situation of a teacher's partial control, but, nevertheless, they write freely ( $\rightarrow$ observed);

- students act independently, although they are guided by a written plan and sketches ( $\rightarrow$ observed);

- students prepare written sketches, however, they practically do not use them in creative writing $(\rightarrow$ observed);

- students perceive the comic book patterns as useful and can justify this (found out $\rightarrow$ when testing), etc.

Three experimental groups participated in the study. The first experimental group included the first-year students with language level A1, studying machinebuilding at the faculty of industrial technologies.

The second experimental group was formed of the second-year students of the Faculty of Economics and Management with language level A2-B1.

Students of the university linguistic center with language level B1-B2 were the respondents in experimental group 3. All experimental groups are shown in Figure 1.

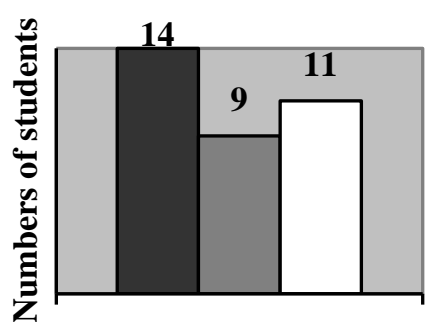

\section{Survey results on the graph}

\section{QGroup $1 \quad \square$ Group 2}

Fig. 1. Experimental Groups on the graphs.

A separate project based on a story in pictures (comics) was developed, observation survey forms and questionnaires were prepared for students in each 
experimental group. Questionnaires are shown in Table 1. Variants of answers for Questionnaires are shown in Table 2.

Table 1. Questionnaires.

\begin{tabular}{|c|c|}
\hline Numerical order & Question \\
\hline 1 & $\begin{array}{l}\text { I have a problem when I am to } \\
\text { formulate a theme (plot) of a } \\
\text { free topic composition }\end{array}$ \\
\hline 2 & $\begin{array}{c}\text { It is difficult for me to write a } \\
\text { text in a foreign language / } \\
\text { express my thoughts }\end{array}$ \\
\hline 3 & $\begin{array}{c}\text { I'm afraid to make grammatical } \\
\text { mistakes when writing in a } \\
\text { foreign language }\end{array}$ \\
\hline 4 & $\begin{array}{c}\text { When writing a free topic } \\
\text { composition, I often do not have } \\
\text { enough vocabulary to express } \\
\text { my thoughts clearly }\end{array}$ \\
\hline 5 & $\begin{array}{l}\text { Plots of comics significantly } \\
\text { reduced the deficit of my } \\
\text { vocabulary }\end{array}$ \\
\hline 6 & $\begin{array}{l}\text { The comic book stories helped } \\
\text { me express my thoughts when } \\
\text { writing a free subject } \\
\text { composition }\end{array}$ \\
\hline 7 & $\begin{array}{l}\text { Plots of comics significantly } \\
\text { reduced the deficit of my } \\
\text { vocabulary }\end{array}$ \\
\hline 8 & $\begin{array}{c}\text { I would like to write a } \\
\text { composition in a foreign } \\
\text { language with the help of comic } \\
\text { book stories again }\end{array}$ \\
\hline 9 & $\begin{array}{l}\text { Where can I apply comics as a } \\
\text { thought (creative) impulse? }\end{array}$ \\
\hline
\end{tabular}

Table 2. Variants of answers.

\begin{tabular}{|c|c|}
\hline Letter value & Answer \\
\hline $\mathrm{a}$ & absolutely right \\
\hline $\mathrm{b}$ & probably yes \\
\hline $\mathrm{c}$ & maybe \\
\hline $\mathrm{d}$ & I think no \\
\hline $\mathrm{e}$ & not in the least \\
\hline
\end{tabular}

The conducted didactic research followed by the survey made it possible to find out that the students' answers, assessments correspond to their language level, and the professions studied. Survey results on the graph are shown in Figures 2-8.

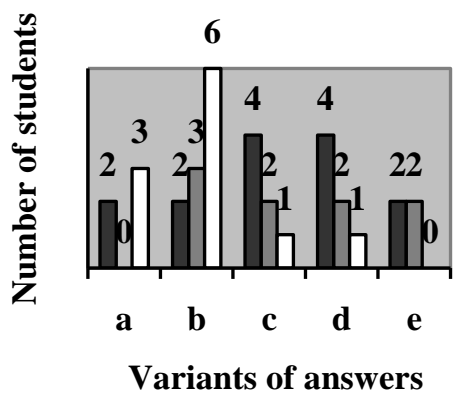

$\square$ Group $1 \square$ Group $2 \square$ Group 3

Fig. 2. Question 1.

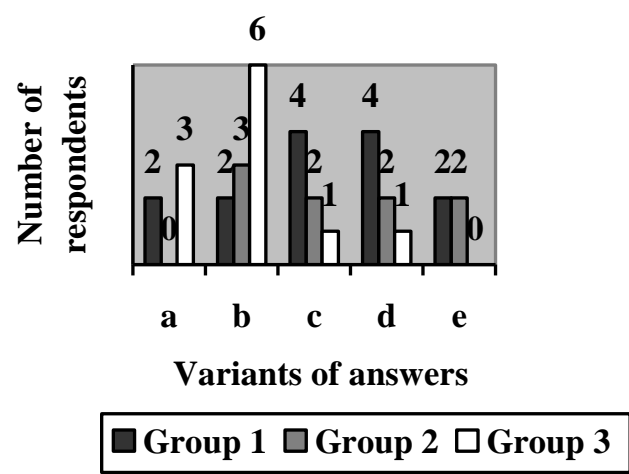

Fig. 3. Question 2.

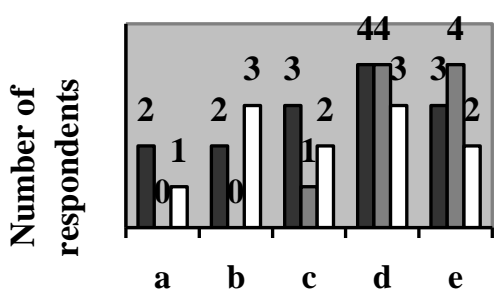

Variants of answers

$\square$ Group $1 \square$ Group $2 \square$ Group 3

Fig. 4. Question 3.

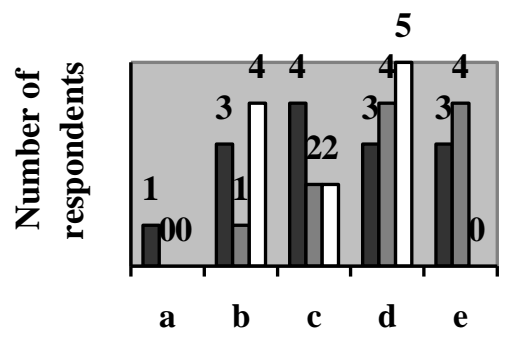

Variants of answers

$\square$ Group $1 \square$ Group $2 \square$ Group 3

Fig. 5. Question 4. 


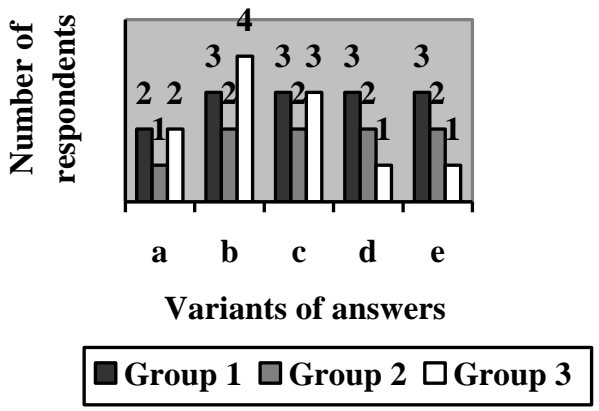

Fig. 6. Question 5.

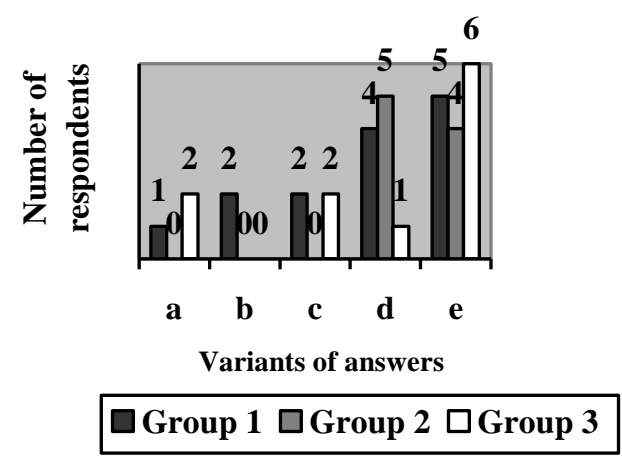

Fig. 7. Question 6.

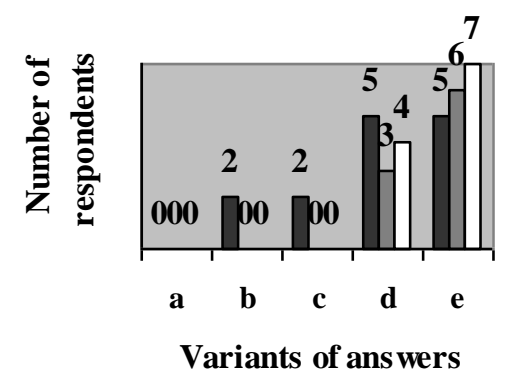

$\square$ Group $1 \square$ Group $2 \square$ Group 3

Fig. 8. Question 7.

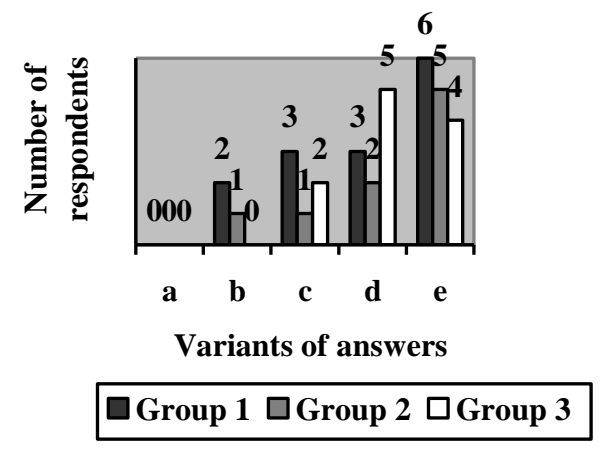

Fig. 9. Question 8.
All the proposed answers to question No. 9 of the questionnaire: "Where can I apply comics as a thought (creative) impulse?" are given in Table 3.

Table 3. Possible situations of using the comics.

\begin{tabular}{|c|c|}
\hline $\begin{array}{c}\text { Experimental } \\
\text { Group }\end{array}$ & Ways of application \\
\hline 1 & $\begin{array}{l}\text { - comics will help me to render } \\
\text { assistance to my brother (sister) } \\
\text { in doing homework in a foreign } \\
\text { language, writing a composition } \\
\text { in Russian; } \\
\text { - in my independent study; } \\
\text { - I cannot give the answer; } \\
\text { - in the further study of the } \\
\text { German language. }\end{array}$ \\
\hline 2 & $\begin{array}{l}\text { - help in the joint writing of a } \\
\text { school essay in Russian with a } \\
\text { younger brother (sister) or an } \\
\text { article for a wall newspaper; } \\
\text { - help brothers and sisters in } \\
\text { learning foreign languages; } \\
\text { - in doing homework in other } \\
\text { subjects; } \\
\text { - in independent study of the } \\
\text { English language; } \\
\text { - in further study of the German } \\
\text { language; } \\
\text { - to write creative works in } \\
\text { Russian; } \\
\text { - to collect ideas for } \\
\text { "brainstorming"; } \\
\text { - when solving puzzle problems. }\end{array}$ \\
\hline 3 & $\begin{array}{l}\text { - to study new foreign words and } \\
\text { regional studies; } \\
\text { - to reconstruct educational } \\
\text { dialogues; } \\
\text { - to make dialogues, to have a } \\
\text { conversation; } \\
\text { - to invent the beginning and the } \\
\text { ending of some creative project; } \\
\text { - to freely speak both the native } \\
\text { and a foreign language, etc. }\end{array}$ \\
\hline
\end{tabular}

\section{Conclusion}

The students of the above specialities participating in the experiment realize their individual difficulties in learning a foreign language in general and developing writing skills in particular, but enjoy the creative writing assignments, since the comics make the writing process amusing and reduce the stress factor.

The linguistic center students, in general, do not experience this kind of linguistic fear and have almost no difficulties in compiling and presenting the stories in written (Storytelling). However, the answer graphs show a distinct positive attitude towards the effectiveness and expediency of using comics in the classroom.

It should be noted that the majority of students in the three experimental groups compiled the story-based comics almost twice as long as autonomously written stories. From the point of view of the learning process, the outcomes received are regarded as positive ones, despite the fact that there happened to be some 
organizational difficulties in the completed research project.

These findings show that the use of comics in class means a significant increase of motivation to writing and the effective overcoming of communicative difficulties and barriers.

\section{References}

1. K.F. Sedov, Discourse and Personality: evolution of communicative competence (M: Labyrinth, 2004)

2. I.A. Zimnyaya, Linguopsychology of speech activity, (Moscow psychological and social institute, Voronezh, 2001)

3. A.C. Omagio, Modern Language Journal, 66, 412 (1982)

4. A.C. Omagio, Canadian modern language reviewrevue canadienne des langues vivantes $\mathbf{3 8}, 517-546$ (1982)

5. C. Dodd, Working in tandem: An Anglo-French project. Developing intercultural competence in practice (Clevedon, UK: Multilingual Matters Ltd., 2001)

6. D. Wolff, Teaching language in context. Proficiency-oriented instruction (Boston: Heinle and Heinle Publishers, Inc., 1989)

7. I.V. Aleshchanova, N.A. Frolova, Modern problems of science and education 4, 87-90 (2010)

8. L. Pires. Brazilian English Language Teaching Journal 1, 139-146 (2010).

9. N.A. Frolova, I.V. Aleshchanova, Herald of Kyrgyz and Russian Slavonic University (Bishkek, Kyrgyzstan) 6,204-207 (2014)

10. H. Funk, C. Kuhn, D. Skiba, Dirk, D. Spaniel-Weise, Dorothea, R. Wicke. Aufgaben, Übungen, Interaktion. Deutsch Lehren Lernen, 4 (München: Klett-Langenscheidt (2014)

11. H. Funk, C. Kuhn, A1. Unterrichtsvorbereitung mit Arbeitsblattgenerator. Kollaboratives Schreibprojekt in Zusammenarbeit mit der Arbeitsstelle für Lehrwerkforschung und Materialentwicklung (ALM) (Berlin: Cornelsenб 2013)

12. B. Kast. Fertigkeit Schreiben. Fernstudieneinheit 12. (Monographie) (Berlin: Langenscheidt, 1999)

13. A.I.Domashnev. Methods of teaching German. Edited by Domashnev Textbook (Moscow: «MSU», 2002)

14. J. Wildfeuer, J Bateman. Visual Narrative Reader 19-66 (2016)

15. T. Allen. Literasy 49, 55(2015)

16. B. Andres, R Poler. INTED Proceedings, 220-227 (2017)

17. K Gavigan. INTED Proceedings, 44650-4655 (2017)

18. MP. Cook, JSJ Kirchoff. Language and literacy 19, 76-95(2017)
19. S. Dvorianchykova, E.Salahatdinova. Science and education 5, 140 (2017)

20. P.Rocamora-Perez, R.Lopez-Liria, JM. AguilarParra, D.Padilla-Gongora, MD. Diaz-Lopez, ME. Vargas-Munoz. Education, health and ICT for a transcultural world 237, 1119-1124 (2017)

21. I.V. Aleshchanova, N.A. Frolova, E.V. Morozova, M.R. Zheltukhina, Proceedings of the 7th International Scientific and Practical Conference Current Issues of Linguistics and Didactics: The Interdisciplinary Approach in Humanities (CILDIAH 2017). Advances in Social Science, Education and Humanities Research (ASSEHR) 97, 19-24. (2017)

22. E. Malushko, O. Maletina, V. Lizunkov, V. Tsybaneva, International Multidisciplinary Scientific Conferences on Social Sciences and Arts, 481-487 (2016)

23. E.V. Bobyreva, O.A. Dmitrieva, M.R. Zheltukhina, M.V. Busygina, Proceedings of the 7th International Scientific and Practical Conference Current Issues of Linguistics and Didactics: The Interdisciplinary Approach in Humanities (CILDIAH 2017). Advances in Social Science, Education and Humanities Research (ASSEHR) 97, 52-56.

24. E. Malushko, O. Maletina, V. Tsybaneva, Advances in Social Science Education and Humanities Research (ASSEHR) 97, 175-180 (2017) 